The education system in China is very different from that in Hong Kong. Because of lack of resources and the emphasis on ideological training, there is little doubt that schools in China are inferior to those in Hong Kong in terms of equipping students with the skills that are necessary for labor market success. This paper compares the rate of return to education between Hong Kong born workers, who received their education locally, and Chinese immigrants to Hong Kong, most of whom attended schools in mainland China. The large difference in quality between Chinese schools and Hong Kong schools provides a "natural experiment" that will be useful towards resolving the question, Does school quality matter?

Recently Card and Krueger (1992a; 1992b) have sparkled renewed interest in the relationship between the quality of schools (measured by class size, term length, teachers' wage, etc.) and students' performance in the labor market. These studies typically make use of variations in school quality over time and across states in the United States. One advantage of using the Hong Kong experience is that the systematic differences in quality of education between schools in Hong Kong and in China are much greater than those across schools in different states. Therefore problems of measurement errors in school quality are of secondary importance. Another advantage of the Hong Kong data is that the choice of schools is exogenous. Immigrants from China had no choice but to enter lower quality schools before they left the country. The link between school quality and returns to schooling is therefore free from the endogeneity bias.

Throughout the history of Hong Kong, immigrants from China have accounted for a significant portion of its population. These Chinese immigrants share the same ethnicity with local born residents, but the difference between their earnings is large and significant. We argue that a large part of this difference is due to school quality differences. In Section I, we document the large differences in resources devoted to schools, in teacher qualification, and in education system and philosophy between Hong Kong and China. According to human capital theory, education improves earnings because education increases market productivity. Thus attending poorer quality schools 
are expected to yield a lower return than attending high quality schools. The theory therefore suggests that the native-immigrant earnings differential will increase with the level of education.

In Section II, we present summary statistics of natives and Chinese immigrants in Hong Kong. Section III briefly explains the human capital approach in the study of the economics of earnings. Using this approach, Section IV addresses the issue of differential returns to education. Because an important deficiency (from the Hong Kong point of view) of the Chinese education system is its lack of proper English language training, this section also discusses the effect of English language ability on earnings. The finding confirms our prediction that the native-immigrant wage gap widens with the level of education. This is consistent with human capital theory but is not consistent with signaling theory. Due to limited places for enrollment, high schools and universities in China are more selective than those in Hong Kong. If education only serves to signal innate ability, university graduates in China should be of exceptional ability, and the native-immigrant wage gap for university graduates should be smaller than that for people with lower levels of education instead.

The Hong Kong census data do not allow unambiguous identification of the place in which schooling is received. For most of the paper, we assume that all Hong Kong born residents attended schools in Hong Kong and all Chinese immigrants attended schools in China. Obviously there are some Chinese immigrants who entered Hong Kong when they were young and these immigrants actually attended Hong Kong schools. To the extent there is a misclassification, this will tend to underestimate the difference in returns to education. In Section V, we test the robustness of our results by using a more limited sample where identification of the place of schooling is less ambiguous. The main conclusions of the paper remain unchanged.

\section{Comparative Education Systems}

In 1990, the Chinese government spent about $2.3 \%$ of GNP on education which ac- 
counted for $12.8 \%$ of public expenditure (UNESCO 1995). The corresponding figures for Hong Kong were higher as she spent $2.8 \%$ of GDP and $17.4 \%$ of public expenditure on education in the same year. However per capita GDP in China was much lower than that of Hong Kong. If one compares their absolute per capita expenditures on education, therefore, Hong Kong is well ahead of China. Per capita government spending on education was around US\$360 in Hong Kong and it was less than US\$10 in China. In interpreting these figures, one should take note that teachers' wages are much lower in China than in Hong Kong. The spending figures may have to be adjusted by a substantial margin in order to make a more meaningful comparison. Nevertheless it is clear that Hong Kong people devote a much greater amount of resources to education than people in mainland China. Money does not necessarily buy quality, but a difference of this magnitude is bound to have significant impact on the differential quality between Hong Kong schools and Chinese schools.

\section{Enrollment in Elementary Education}

Free and universal education in Hong Kong started in 1971 for primary schools and was extended to junior secondary schools in 1978. The attendance rate for children aged 6-11 grew gradually from 94.9 percent in 1971 to 99.8 percent in 1991.

The school attendance rate grew much more rapidly in China. The attendance rate for primary school aged children was only 25.0 percent in 1949 . This figure jumped to 84.7 percent in 1967 and then rose further to 96.0 percent in 1976. In 1989 the official enrollment rate stood at 97.4 percent (Cheng 1992; Pepper 1990). Such a high attendance rate is comparable to that of any developed countries in the world. This astonishing situation, however, is partly achieved by compromising quality for quantity. To rapidly expand education to the rural areas, the Chinese government sent many educated urban youth without training in education to become teachers in the countryside. They taught in "part-work primary schools" (village schools). These schools were very small and had virtually no facilities. A single (and sometimes the only) teacher might 
have to travel around and taught at a number of village schools periodically. It is not uncommon that students of different grades attended classes in the same room concurrently. Hence it is very difficult, if not impossible, to maintain a high level of education quality.

\section{Teacher Qualifications}

In China a qualified primary teacher refers to a junior middle school graduate who has received three years of formal teaching training. According to this criterion, only 39.4 percent of primary school teachers were qualified in 1988 (Cheng 1992). If one relaxes the requirement by including all senior middle school graduates as qualified teachers, the proportion would increase to 68.1 percent. The situation is even worse in junior secondary schools, in which only 35.6 percent of all teachers are "qualified". ${ }^{1}$

The situation in Hong Kong is far better than that in China. A qualified primary school teacher refers to a person with a teacher's certificate from a college of education (normally requiring three years of training after secondary school) or higher standard. In 1988 slightly more than ten percent of all primary teachers were untrained nongraduates. Among these untrained non-graduates, some of them were post-secondary graduates, who received two to three years of education after matriculation. They have actually attained a higher educational level than that of a "qualified" teacher in China.

\section{English Language Skills}

English language is not commonly taught at school level in China. Students are not exposed to English in primary schools, and only some secondary schools offer English language as an academic subject. In fact English teachers were once classified as "backward elements" in the 1950's. At that time, English teachers frequently suffered from personal attacks, and overseas materials in English were scrutinized by authorities. To cite one example, Wu Ningkun, a doctoral student in the United States, was called back to teach English and American Literature at Beijing University in 1951. As an

\footnotetext{
${ }^{1}$ A qualified junior secondary school teacher is one who has attained university standard.
} 
intellectual, Wu was labeled as "rightist" and was dragged out of bed in the middle of the night and was beat and kicked by his students (Cherrington 1991). Given such a background, knowledge of English language may be regarded as a bad instead of a good. Thus one should expect the majority of Chinese immigrants do not speak English.

The situation in Hong Kong is quite different. Not until recently, English is the only official language in the territory, though most residents speak the Cantonese dialect. English is taught from kindergarten to university level. Many primary and secondary schools use English as the language of instruction. Besides, English language is one of the three core subjects in the education system (the other two are Mathematics and Chinese Language). With the introduction of nine-year free education since 1978, anyone brought up in Hong Kong are expected to understand basic English.

\section{Orientation of the Education Systems}

The development of China's education system, and higher education in particular, lags behind other developed and developing countries. An academic degree system was first introduced in 1981 and bachelor's and master's degrees started to be conferred in the same year. The first batch of 13 doctorate degree graduates were trained in 1982 (Cheng 1992). ${ }^{2}$ The Chinese education system puts primary focus on the indoctrination of communist ideology. Price (1979, p. 284) states that during the Cultural Revolution from 1966 to 1969, "Education here [in China] is the production of consciousness in Marx's sense, as distinct from the learning of skill such as reading and writing...." Mao Zedong wanted to use the students as a lever to social and political change and school curricula were dominated by moral-political teaching. ${ }^{3}$ Before the introduction of the nation-wide college entrance examination in 1977, admission criteria emphasized more on class background and political suitability than on academic ability. ${ }^{4}$ Nowadays

\footnotetext{
${ }^{2}$ Although the Hong Kong population is less than one percent the size of China's population in 1982, there were 22 doctoral degrees conferred by local universities in that year (Census \& Statistics Department 1992).

${ }^{3}$ See Lo (1987) for detailed discussion of Mao's theories on China's education.

${ }^{4}$ See Pepper (1990) and Xu, Xu and Guo (1986) for detailed account of the development of China's education system.
} 
moral-political education still constitutes a significant portion of the school curricula. Moreover, because of wage compression under the communist system, the Chinese labor market does not reward academic excellence, and the expected returns from studying hard at school are small. These characteristics suggest that immigrants educated in China should have received less training on academic subjects, and have invested less time studying them. If knowledge of traditional academic subjects can raise one's wage rate, Chinese immigrants are at a disadvantageous position when compared with natives.

In contrast the Hong Kong education system follows closely the British "elitist" tradition. Students' performance in public examinations is the main concern of their teachers, and teachers will be blamed by students if they do not follow closely the public examination syllabuses. Many jobs have formal educational requirements. Academic excellence is considered a license to success in the labor market.

\section{Statistical Portrait of Natives and Chinese Immigrants}

The data set used in this study is the five percent sample of the population census conducted in Hong Kong in March 1991. Members of all households in Hong Kong were required, by law, to participate in the census. The resulting data file provides up-to-date information about the population. Because of the intermittent labor force participation of women, this paper only focuses on male workers. We select for analysis men who are (i) aged 15 to 64; (ii) born in Hong Kong or China; (iii) worked in the census reference week; and (iv) received positive earnings from main employment. ${ }^{5}$ Employers and selfemployed persons are excluded, as part of their income is capital income which is not the return on educational investment. We also exclude workers who are studying full-time. In the five percent sample file, 37,889 natives and 24,520 immigrants from China fulfill the above sample selection criteria.

\footnotetext{
${ }^{5}$ Although it would be better to focus on full-time workers, the 1991 population census did not collect information about hours of work. However, Lui and Suen (1993) show that the size of the coefficient for the hours of work variable on log earnings is small (less than 0.0015 for the census years 1976, 1981, and 1986). Besides, the underemployment rate was around 1 percent in the first quarter of 1991 when the census was conducted.
} 
Since natives and Chinese immigrants have the same ethnicity, those Chinese inhabitants who migrated to Hong Kong in their childhood may be indistinguishable from natives when they grew up. These immigrants most likely are educated in Hong Kong and have the same returns to education as natives. If natives have higher returns to education than Chinese immigrants (as will be shown below), this particular group of immigrants will increase the estimated returns to schooling in China. Therefore, the reported estimates of returns to schooling in China is biased upward. Besides some Chinese immigrants are educated overseas prior to their arrival in Hong Kong. Assuming overseas education has a higher quality than education in mainland China, the presence of these individuals will also make our estimated returns to Chinese schooling upward biased. As a result, the actual differential returns to education of natives and Chinese immigrants are wider than the estimates reported below.

Table 1 displays the socio-economic characteristics of natives and Chinese immigrants in Hong Kong in 1991. The mean age of local born workers is 32, which is 12 years younger than that of Chinese immigrant workers. As Chinese immigrants are older, they are more likely to be married. As expected, the mean earnings of natives is substantially higher than that of immigrants, and the difference is statistically significant. The immigrant-native mean earnings ratio is 0.76 . We also compute the difference in mean $\log$ earnings, and this difference is 0.23. Both mean earnings and mean log earnings suggest that the earnings of Chinese immigrants are about three-quarter of their native counterparts.

On average, natives have received 9.97 years of schooling, which is 2.37 more years than Chinese immigrants. We also categorize the sample by educational level. More than half of the native workers reach upper secondary or higher levels, whereas this proportion drops to 28 percent for Chinese immigrants. Among natives, 8 percent of them were university degree holders and 9 percent of them received post-secondary (non-degree) education; the corresponding figures for immigrants from China are 4 percent and 3 percent respectively. According to human capital theory, ceteris paribus, this difference 
in educational attainment indicates that natives should earn more than immigrants from China. If Chinese schools are inferior schools, as we have documented in the previous section, the gap between native and immigrant earnings should also widen with years of schooling.

A second issue addressed in this paper is the returns to English speaking ability. We classify a person as being able to speak English if he reported this language being used in daily communication. ${ }^{6}$ While about half of natives are able to speak English, only 14 percent of Chinese immigrants have this language ability. This difference is consistent with the fact that English is being taught in Hong Kong as early as in kindergarten.

\section{The Economics of Earnings}

The concept of human capital was first shaped by Adam Smith more than two centuries ago. However, the systematic economic analysis of human capital formation and its implications for labor economics were developed rapidly only since the last three decades. In analyzing the economics of earnings, the most frequently used method is the human capital earnings equation developed by Jacob Mincer (1974). ${ }^{7}$ Since the pioneering work of Mincer, there is a huge literature applying, modifying, or extending his earnings equation. To cite but one example, Murphy and Welch (1990) argue that the quadratic specification systematically misses important features of the age-income profile and they propose to use fourth order polynomial in the earnings regression. Moreover, human capital theory has been extensively used to explain various labor market phenomena such as migration, income distribution, female labor force participation and investment in on-the-job training. ${ }^{8}$

\section{Earnings Equation}

Mincer's basic earnings equation is to regress log earnings on years of schooling

\footnotetext{
${ }^{6}$ Our results show that Cantonese and Putonghua speaking abilities do not affect one's earnings ability. We choose not to include these abilities in our analysis.

${ }^{7}$ See Polachek and Siebert (1993) for a detailed survey of the theoretical developments of the human capital approach in labor economics.

${ }^{8}$ See Ehrenberg and Smith (1994) for a brief review of the applications of human capital theory.
} 
and on a quadratic in years of work experience, i.e.,

$$
\log Y=\alpha+\beta S+\gamma_{1} E+\gamma_{2} E^{2}
$$

where $\log Y$ is the natural logarithm of earnings, $S$ is the years of schooling, and $E$ is the years of work experience. In many survey data, information on actual work experience is unavailable and potential work experience (defined as age minus schooling minus six) has to be used instead. Other demographic characteristics such as marital status are often added to the basic regression to serve as controls.

The schooling coefficient $\beta$ is a measure of the rate of return to schooling. Suppose a worker increases his investment in education from $s$ years to $s+1$ years, ceteris paribus, the change in log earnings is:

$$
\log Y_{s+1}-\log Y_{s}=\beta(s+1)-\beta s=\beta
$$

For small $\beta$, the above can be approximated as

$$
\frac{Y_{s+1}-Y_{s}}{Y_{s}}=\beta
$$

Thus, if the coefficient estimate of the schooling variable is small, the estimate can be approximated as percentage change in earnings per additional year of schooling. Similarly, in a study of immigrant earnings, the coefficient on the duration of residence can be interpreted as the percentage change in earnings per additional year of of stay in the host country.

\section{Decomposition of the Earnings Differential}

In analyzing the earnings differential between natives and Chinese immigrants, we can follow the decomposition methods used by Blinder (1973) and Oaxaca (1973). They propose to separate the earnings differentials into two components as follow:

$$
\bar{y}_{n}-\bar{y}_{i}=\bar{X}_{n}\left(b_{i}-b_{n}\right)+b_{i}\left(\bar{X}_{i}-\bar{X}_{n}\right),
$$

or, changing the base of decomposition,

$$
\bar{y}_{n}-\bar{y}_{i}=\bar{X}_{i}\left(b_{i}-b_{n}\right)+b_{n}\left(\bar{X}_{i}-\bar{X}_{n}\right),
$$


where $\bar{y}_{n}$ is the mean of native log earnings, $\bar{y}_{i}$ is the mean of immigrant log earnings, and $b_{n}$ and $b_{i}$ are estimated coefficients vectors for natives and for immigrants, respectively. The first term of both methods shows the differing returns to individual characteristics (the coefficients effect), while the second term reflects the effect of differing personal characteristics (the endowments effect). However, these two methods of decomposition of the coefficients and endowments effects depend very much on the chosen base. Our analysis indicate that the two estimated effects vary considerably between these methods. A good compromise is to decompose the two effects by the following method:

$$
\left(\frac{\bar{X}_{i}+\bar{X}_{n}}{2}\right)\left(b_{i}-b_{n}\right)+\left(\frac{b_{i}+b_{n}}{2}\right)\left(\bar{X}_{i}-\bar{X}_{n}\right)
$$

In the above expression, the first term shows the effect of differing returns to personal characteristics, and the second term captures the effect of differing personal characteristics. In this paper, the third method is used to decompose the earnings differential between natives and immigrants.

\section{Returns to Education and Language Ability}

We employ the human capital earnings equation (Mincer 1974) to estimate the determinants of main employment earnings. The dependent variable is the natural logarithm of main employment earnings and the independent variables include potential experience (age minus schooling minus six), experience squared, and four sets of dummy variables for immigrant status, marital status, educational attainment and language ability.

We run three earnings regression on the full sample as well as on separate subsamples of native workers and immigrant workers. The first column on Table 2 refers to the parameter estimates using the full sample, whereas columns (2) and (3) refer to earnings regressions for natives and for immigrants from China. All coefficients are statistically significant and have the expected signs. For the full sample, the earnings function explains $41 \%$ of the variance in log income. From column (1) of Table 2, the coefficient for the Chinese immigrant dummy is -0.1399 , which suggests that immigrants 
from China on average earn $13 \%$ (i.e., $1-e^{-.1399}$ ) less than their native counterparts. Looking at the education dummies, the estimated coefficients indicate that investment in education yields fairly high return. For example, a university graduate earns $166 \%$ more than an uneducated worker after controlling for other personal characteristics. These results are consistent with the predictions of human capital theory.

Assuming the coefficients on individual characteristics are the same for natives and for immigrants from China, we can decompose the earnings differential into two components: (a) the unexplained earnings gap, i.e., the estimated coefficient for the Chinese immigrant dummy; and (b) the endowments effect, i.e., the earnings gap due to differing endowments, which is measured by $b\left(\bar{X}_{i}-\bar{X}_{n}\right)$, where $b$ is the vector of estimated coefficients and $\bar{X}_{i}$ and $\bar{X}_{n}$ are the vectors of sample means of individual characteristics of immigrants and natives. Using this method of decomposition, it is estimated that the unexplained earnings gap is 14 percent (14 log points, to be precise) and the endowments effect is 9 percent. Thus, on average, immigrants from China earn 23 percent less than natives. If natives and immigrants have the same education endowments, the earnings gap will be reduced by 11 percentage points (log points). Similarly, if natives and Chinese immigrants are equally good in English, the earnings gap will be narrowed by 10 percentage points.

Equation (1) in Table 2 forces the coefficients on the demographic characteristics to be the same across natives and immigrants. However, as we argue in Section I, the difference in school quality suggests that the returns to education may be systematically different across the two groups of workers. Columns (2) and (3) in Table 2 show the estimated coefficients of separate earnings regressions for natives and for immigrants. Comparing the parameter estimates on the education dummies in columns (1) and (2), one can see that the returns to education is higher for natives than for the full sample. On the other hand, comparing columns (1) and (3), the education premium for Chinese immigrants is substantially lower than that for the full sample. From Column (2) of Table 2, local born degree holders earn 269\% more than local born uneducated persons. 
For Chinese immigrants, university graduate workers only receive an earnings advantage of 75 percent when compared with uneducated workers. This represents a reduction in education premium for immigrant university graduates of more than 194 percentage points. Similarly the earnings advantage for immigrant secondary school leavers relative to uneducated immigrants is only 16 percent, compared to the 27 percent premium for native secondary school leavers.

Table 2 also shows that the return to English ability is substantially higher for immigrants from China than for natives. Chinese immigrants who can speak English probably received a better than average education than other Chinese immigrants. It is also possible that some of them actually received their education locally in Hong Kong. If so, the higher coefficient on English ability for Chinese immigrants is partly a reflection of returns to school quality.

Following the decomposition method employed by Blinder (1973) and Oaxaca (1973) as in Section III, the earnings differential can approximately be decomposed into two components:

$$
\left(\frac{\bar{X}_{i}+\bar{X}_{n}}{2}\right)\left(b_{i}-b_{n}\right)+\left(\frac{b_{i}+b_{n}}{2}\right)\left(\bar{X}_{i}-\bar{X}_{n}\right)
$$

where $b_{i}$ and $b_{n}$ are the estimated coefficient vectors for immigrants and for natives in their earnings separate regressions. The first term shows the effect of differing returns to personal characteristics (the coefficients effect). The second term captures the effect of differing personal characteristics between the two groups (the endowments effect). From our regression results, the estimated coefficients and endowments effects are -0.105 and -0.123 respectively. If education investment is valued equally, the earnings gap can be reduced by 20 percentage points (log points). Moreover, differing education endowments explain another 11 percentage points of the earnings gap.

To give a simple summary of the differing returns to education, we include years of schooling instead of education level dummies in another set of earnings regressions. Using the full sample, an additional year of schooling will increase one's earnings by 6.8 percentage points. Using the sample of natives alone, the rate of return to educational 
investment rises to 10.8 percent per year of schooling. As expected, the education premium drops to 3.1 percent for Chinese immigrants. In other words, ceteris paribus, the native-immigrant earnings gap increases by 7.7 percentage points per additional year of schooling.

Another way of thinking about the differential returns to education is to consider how the immigrant earnings gap varies with education level. According to signaling theory, Chinese immigrants who managed to attain high levels of education should be of exceptional quality since the education system in China is more selective than that in Hong Kong. If schooling does not contribute to productivity, the theory will predict a native-immigrant earnings gap that narrows with advancing education level. Similarly Schultz (1975) argues that education improves people's ability to deal with disequilibrium. If there is no difference in the quality of schools, one should expect that highly educated Chinese immigrants should be more able to adapt to the host city and they should therefore suffer a smaller earnings disadvantage compared to immigrants with less schooling. On the other hand, according to human capital theory, education improves earnings because education increases labor market skills. Since Hong Kong schools are of a higher quality (both in terms of resources and in terms of emphasis on marketable skills) than Chinese schools, one should expect to observe a native-immigrant earnings gap that widens with the level of education.

We sub-divide the full sample into 7 groups by educational attainment. We then run a separate earnings regression on each group. The coefficient on the variable for Chinese immigrants captures the unexplained earnings disadvantage of immigrants. To save space we only present the coefficient estimates of Chinese immigrant status and of English speaking ability of these 7 regressions in Table 3. All other coefficient estimates are statistically significant and have the predicted signs. Table 3 clearly shows that the native-immigrant earnings gap increases with every level of educational attainment. Uneducated native workers face an earnings advantage of 6 percent when compared with their immigrant counterparts. For workers with university degrees the earnings gap is 
the highest, namely, 35 percent.

It is generally believed in Hong Kong that possessing English speaking ability increases one's earnings capacity. This is confirmed by the results in Tables 2 and 3 . From Table 3, we can see that English education pays handsomely. On average, English speaking secondary school graduates earn 23 percent more than those who cannot speak English in daily communication. This language premium jumps to 105 percent for degree holders.

Our results have important implications for other empirical studies on human capital investment in Hong Kong. The above analysis suggests that the Hong Kong education system trains more productive workers than the education system in China. Since a substantial portion of the Hong Kong population did not receive their education from local schools, estimates of the returns to education using the entire sample of Hong Kong (native and immigrant) workers will underestimate the rate of return from local

schools. Most researchers (e.g., Psacharopoulos 1985; Kwok 1992; Wong 1992) do not remove Chinese immigrants from their samples, and their estimates of rates of return to local educational investment are therefore biased downward. Our results show that such bias is quantitatively very important.

\section{Recent vs. Early Chinese Immigrants}

Numerous studies in developed countries (e.g., Chiswick 1978; Borjas 1988) suggest that the duration of residence in the host countries will affect the performance of immigrants in the labor market. So we sub-divide the immigrant sample into recent and early immigrant samples. We classify those who had resided in Hong Kong for five or fewer years as recent immigrants. People who were born in China but had been in Hong Kong for more than five years are classified as early immigrants. In the five percent sample, there are 1,194 and 23,326 recent and early Chinese immigrants respectively. We use two dummies to represent these two groups. In the earnings regression for all workers the estimated coefficient for recent immigrants is -0.304 and that for early immigrants 
is -0.127 . This gives a recent-early immigrant earnings ratio of 0.84 after controlling for personal characteristics.

Not only do recent immigrants earn less than early immigrants, they also experience a lower rate of return to schooling. In Table 4 we show separate earnings regressions for these two groups. Comparing columns (1) and (2), the estimated coefficients on the education variables are generally larger for early immigrants than for recent immigrants. We do not have information about the place in which a person obtained his education. However it is reasonable to infer that early immigrants are more likely to have received their education in Hong Kong than are recent immigrants. This is because early immigrants tend to arrive in Hong Kong at a younger age than more recent immigrants, holding age at the time of census constant. The comparison of the rates of return to education for these two groups of immigrants therefore reinforces our argument that schooling in China yields a lower return than schooling in Hong Kong. ${ }^{9}$

As the main focus of the paper is to analyze the different returns to schooling in Hong Kong and schooling in China, it would be ideal if we can separate those immigrants who received their education in China from those who were educated in Hong Kong. In the census data file, we know the exact year an immigrant arrived in Hong Kong provided his duration of residence in the city is less than ten years. We can separate these immigrants into two groups. If the years of labor market experience (age minus schooling minus six) for an immigrant is less than his years of residence in Hong Kong, we infer that he had received part of his education in Hong Kong. This group is labeled Group 1. If the years of labor market experience is equal to or greater than the duration of residence in Hong Kong, the person is assumed to have completed his education in China, and he is said to belong to Group 2. For each of these two groups, we run an earnings regression on English ability, schooling, experience, experience squared, marital status and years of residence. Table 5 reports the results. The duration of residence variable

\footnotetext{
${ }^{9}$ See Lam and Liu (1993a; 1993b; 1997) for more detailed analysis of assimilation and the economic performance of different cohorts of immigrants.
} 
is positive for Group 2 individuals, indicating assimilation into the local economy. This variable, however, is not significantly different from zero in the Group 1 regression. More interestingly, the coefficient estimates for the schooling variable are substantially different across the two groups. The rate of return to schooling for Group 1 (immigrants educated in Hong Kong) is 5.5 percent; while that for Group 2 (immigrants educated in China) is only 3.1 percent. Thus even a few years of exposure to Hong Kong schools will raise the returns to education by 2.4 percentage points.

\section{Summary and Some Policy Implications}

The main findings of this paper can be summarize as follows:

1. Although natives and immigrants from China have the same ethnicity, the difference in earnings between natives and Chinese immigrants is significant. The raw earnings gap of working males is estimated to be around 24 percent.

2. The rate of return to education is 10.8 percent for natives but it is only 3.1 percent for Chinese immigrants. Differing returns to education explains a large part of the earnings gap. If education is valued equally for natives and Chinese immigrants, the earnings gap can be reduced by 20 percentage points.

3. The earnings dispersion between natives and immigrants from China increases with level of educational attainment after controlling for personal characteristics.

4. Workers who can speak English earn substantially more than those who do not. English speaking workers who are born in Hong Kong enjoy an earning advantage of 18 percent when compared with non-English speaking workers. This premium increases to 53 percent for Chinese immigrants.

5. Immigrants who received part of their education in Hong Kong get a 2.4 percentage point higher rate of return to schooling than those who had completed their education before arriving in Hong Kong. 
We argue that the differing returns to education for natives and for immigrants arise largely from differences in the quality of schooling. Human capital theory suggests that the returns to education is an increasing function of the quality of education. Because of dramatic quality differences between Hong Kong schools and Chinese schools, the experience in the Hong Kong labor market provides convincing evidence that school quality matters.

This paper also points out that earlier studies of economic returns to educational investment in Hong Kong are seriously biased. Because these studies fail to make a distinction between natives and immigrants, their estimated rate of return to schooling is a weighted average of the returns to Chinese education and the returns to Hong Kong education. Correcting such bias will raise the rate of returns to local investment in education from 6.8 percent to 10.8 percent. It is therefore crucial to distinguish between the labor market experience of those educated in Hong Kong and those educated elsewhere in making education and manpower policies.

Our analysis also shows that immigrants who received at least part of their education in Hong Kong schools enjoy higher returns to education than those who had completed their education before arriving in the territory. When China resumes her sovereignty of Hong Kong, a large number of offsprings of local citizens are eligible by rights to stay in Hong Kong. If the returns to local education are much higher than education in China, we should encourage these children to come to Hong Kong earlier so that they can have access to local education as soon as possible.

English is a very important medium of communication in the business sector in Hong Kong and a good facility to English will substantially increase one's earnings capacity. This paper indicates that English education pays handsomely in Hong Kong. In the past few years, local education administrators often complain about the lowering of English standard of students at all levels. English foundation courses are introduced in all government funded tertiary institutions and are made compulsory for selected students. The findings in this paper suggest that such concerns about the standard of 
English ability are justified. Hopefully the results presented in this paper may encourage students and educators to spend more time and effort in the English language. 


\section{References}

Blinder, Alan S. "Wage Discrimination: Reduced Form and Structural Variables." Journal of Human Resources 8 (1973): 436-455.

Borjas, George J. International Differences in the Labor Market Performance of Immigrants. Kalamazoo: Upjohn Institute, 1988.

Card, David and Alan B. Krueger. "Does School Quality Matter? Returns to Education and the Characteristics of Public Schools in the United States." Journal of Political Economy 100 (February 1992a): 1-40.

—. "School Quality and Black-White Relative Earnings: A Direct Assessment." Quarterly Journal of Economics $10^{r 7}$ (February 1992b): 151-200.

Census and Statistics Department. Hong Kong Annual Digest of Statistics. Hong Kong: Government Printer, 1992.

Cheng, Kai-Ming. Zhongquo Jiaoyu Gaige. (Education Reform in China.) Hong Kong: The Commercial Press, 1992. (in Chinese)

Cherrington, Ruth. China's Students: The Struggle for Democracy. New York: Routledge, 1991.

Chiswick, Barry R. "The Effect of Americanization on the Earnings of Foreign-Born Men." Journal of Political Economy 86 (October 1978): 897-921.

Ehrenberg, Ronald G. and Robert S. Smith. Modern Labor Economics: Theory and Public Policy. 5th Edition. New York: Harper Collins Publishers Inc., 1994.

Kwok, Kwok-Chuen. "An Analysis of the Earnings Structure." In Pak-Wai Liu and Richard Yue-Chim Wong (eds.) The Economics and Financing of Hong Kong Education. Hong Kong: Chinese University Press, 1992.

Lam, Kit-Chun and Pak-Wai Liu. Economic Performance of New Immigrants in Hong Kong. Working Paper Series No. ES92037, Business Research Centre, Hong Kong Baptist College, 1993a. 
—. Are Immigrants Assimilating Better Now Than a Decade Ago? The Case of Hong Kong. Occasional Paper Series, Hong Kong Institute of Asia-Pacific Studies, The Chinese University of Hong Kong, 1993b.

- Earnings Divergence and Assimilation of Immigrants. Working Paper No. 83, Department of Economics, Chinese University of Hong Kong, 1997.

Lo, Nai-Kwai. "Mao Zedong's Developmental Theories and their Influence on Contemporary Chinese Education." Education Journal 15 (December 1987): 26-38.

Lui, Hon-Kwong and Wing Suen. "The Narrowing Gender Gap in Hong Kong: 19761986." Asian Economic Journal 7 (July 1993): 167-180.

Mincer, Jacob. Schooling, Experience and Earnings. New York: National Bureau of Economic Research, 1974.

Murphy, Kevin M. and Finis Welch. "Empirical Age-Earnings Profiles." Journal of Labor Economics 8 (April 1990): 202-229.

Oaxaca, Ronald. "Male-Female Wage Differentials in Urban Labor Markets." International Economic Review 14 (October 1973): 693-709.

Pepper, Suzanne. China's Education Reform in the 1980s: Policies, Issues, and Historical Perspectives. China Research Monograph No. 36, Institute of East Asian Studies, University of California at Berkeley, 1990.

Polachek, Solomon W. and W. Stanley Siebert. The Economics of Earnings. Cambridge: Cambridge University Press, 1993.

Psacharopoulos, George. "Returns to Education: A Further International Update and Implications." Journal of Human Resources 20 (Fall 1985): 583-604.

Schultz, Theodore W. "The Value of the Ability to Deal with Disequilibria." Journal of Economic Literature 13 (1975): 872-876.

UNESCO. Statistical Yearbook. 1995 Edition. [Paris: UNESCO, 1995.] 
Wong, Ka-fu. "Private and Social Rates of Return to Investment in Education." In Pak-Wai Liu and Richard Yue-Chim Wong (eds.) The Economics and Financing of Hong Kong Education. Hong Kong: Chinese University Press, 1992.

Xu, Mingdi, Jianquan Xu and Sile Guo. "An Experimental Reform in China's Primary and Secondary School Systems." Education Journal 14 (December 1986): 95100. (in Chinese) 
Table 1

Characteristics of Native and Chinese Immigrant Workers in 1991

\begin{tabular}{lcc}
\hline Variable & Natives & Immigrants \\
\hline Age (Years) & 31.65 & 43.00 \\
Schooling (Years) & 9.97 & 7.60 \\
Working Experience (Years) & 15.82 & 29.57 \\
Income (\$) & 8,353 & 6,343 \\
Log(Income) & 8.81 & 8.58 \\
& & \\
Marital Status (\%) & & \\
Married & 47 & 80 \\
Widowed/Separated & 1 & 2 \\
& & \\
Educational Attainment (\%) & & \\
Primary & 16 & 37 \\
Lower Secondary & 25 & 27 \\
Upper Secondary & 34 & 18 \\
Matriculation & 6 & 3 \\
Post-secondary & 9 & 3 \\
Degree & 8 & 4 \\
English Speaking (\%) & 51 & 14 \\
N & & \\
& 37,889 & 24,520 \\
\hline
\end{tabular}


Table 2

\section{Earnings Regressions for Natives and Immigrants}

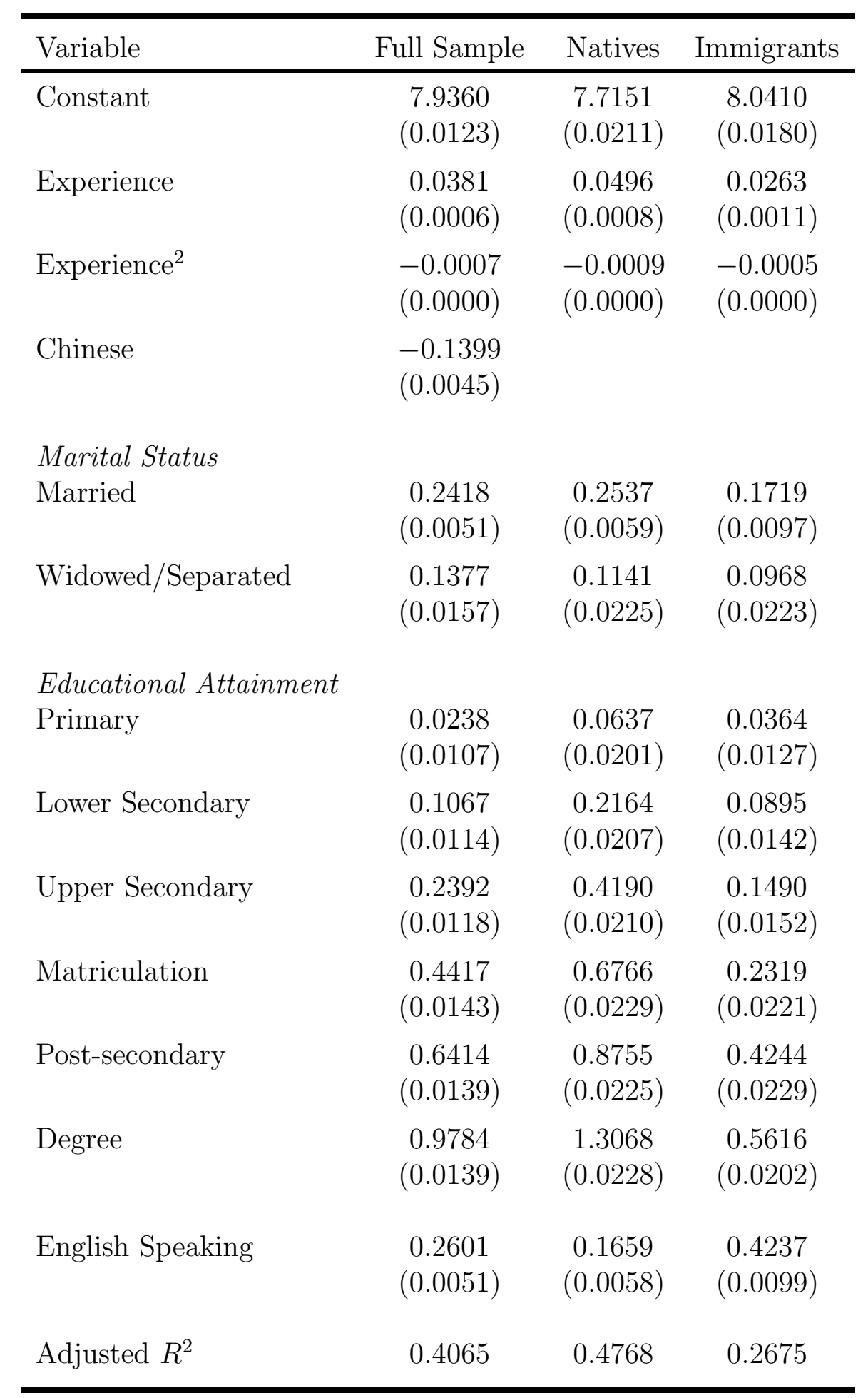

Standard errors are shown in parentheses. 
Table 3

Coefficients for Chinese Immigrant and English Speaking Dummies by Educational Level

\begin{tabular}{lcc}
\hline Educational Level & Chinese Immigrants & English Speaking \\
\hline No Schooling & -0.0597 & 0.1663 \\
& $(0.0217)$ & $(0.0758)$ \\
Primary & -0.0724 & 0.2288 \\
& $(0.0078)$ & $(0.0169)$ \\
Lower Secondary & -0.0794 & 0.1419 \\
& $(0.0076)$ & $(0.0089)$ \\
Upper Secondary & -0.1628 & 0.2110 \\
& $(0.0087)$ & $(0.0071)$ \\
Matriculation & -0.2283 & 0.4434 \\
& $(0.0255)$ & $(0.0240)$ \\
Post-secondary & -0.2410 & 0.3945 \\
& $(0.0240)$ & $(0.0229)$ \\
Degree & -0.4282 & 0.7155 \\
& $(0.0279)$ & $(0.0318)$ \\
\hline
\end{tabular}

Standard errors are shown in parentheses. 
Table 4

Earnings Regressions for New and Old Immigrants

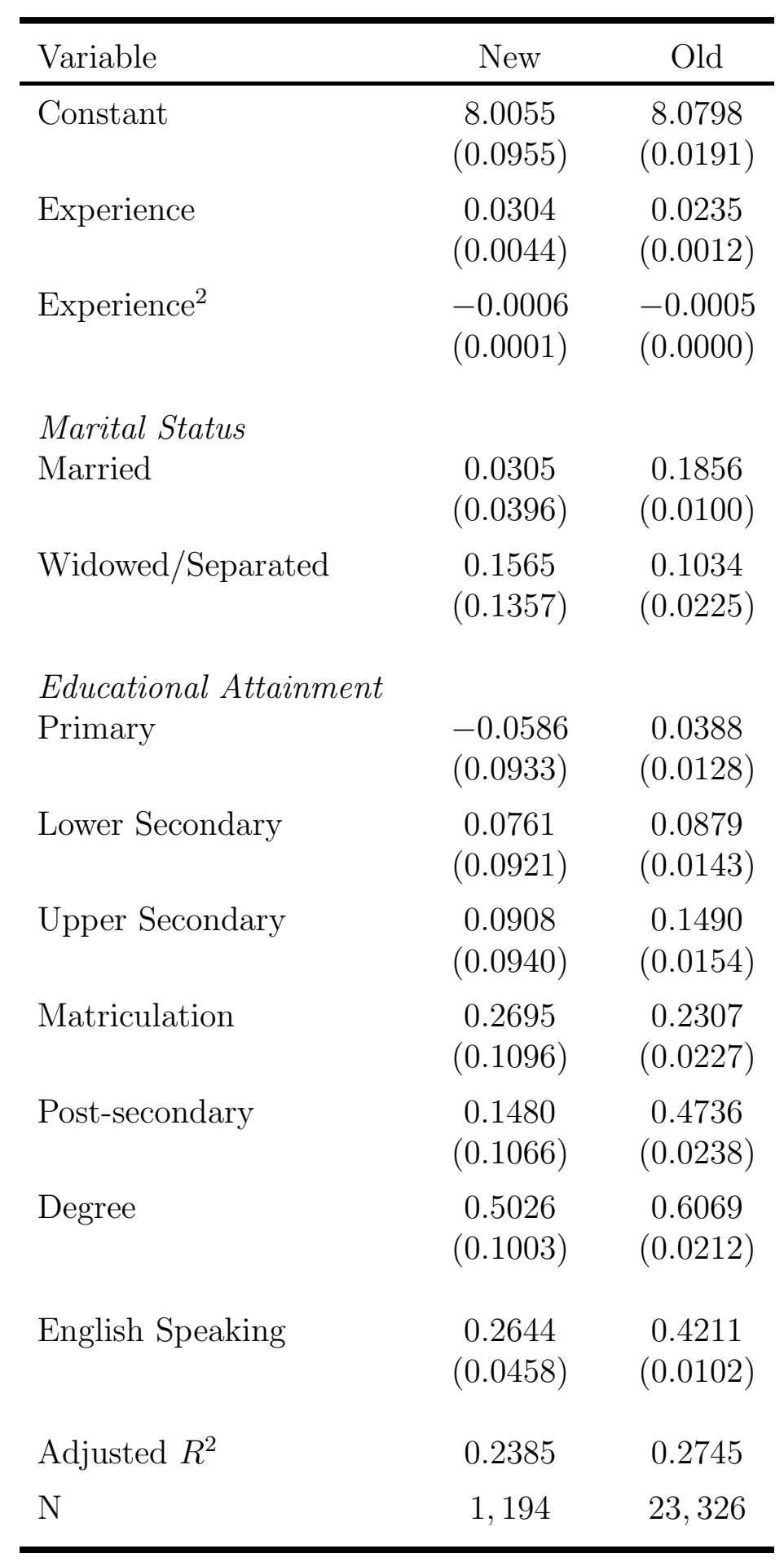

Standard errors are shown in parentheses. 
Table 5

\section{Earnings Regressions for Immigrants Educated in Hong Kong and Immigrants Educated in China}

\begin{tabular}{lcc}
\hline Variable & $\begin{array}{c}\text { educated in Hong Kong } \\
\text { (Group 1) }\end{array}$ & $\begin{array}{c}\text { educated in China } \\
\text { (Group 2) }\end{array}$ \\
\hline Constant & 7.6836 & 7.8490 \\
& $(0.1584)$ & $(0.0420)$ \\
Experience & 0.0446 & 0.0243 \\
Experience & $(0.0407)$ & $(0.0036)$ \\
& 0.0001 & -0.0005 \\
Duration of Residence & $(0.0043)$ & $(0.0001)$ \\
Married & -0.0125 & 0.0108 \\
& $(0.0143)$ & $(0.0035)$ \\
Schooling & 0.2849 & 0.0534 \\
& $(0.0963)$ & $(0.0268)$ \\
English Speaking & 0.0539 & 0.0302 \\
& $(0.0109)$ & $(0.0030)$ \\
Adjusted $R^{2}$ & 0.0224 & 0.3504 \\
N & $(0.0666)$ & $(0.0334)$ \\
\hline
\end{tabular}

Standard errors are shown in parentheses. 


\title{
Does School Quality Matter? \\ Evidence from the Hong Kong Experience
}

\author{
Hon-Kwong Lui* \\ (Lingnan College) \\ and \\ Wing Suen \\ (The University of Hong Kong)
}

December 1997

Abstract. This paper analyses the differential returns to education and to language ability of natives and Chinese immigrants in Hong Kong. The large difference in quality between Hong Kong schools and Chinese schools provides a natural experiment for evaluating the effect of school quality on students' performance in the labor market. We show that the rate of return to schooling is more than three times higher among local born workers than among Chinese immigrants to Hong Kong. Our analysis also suggests that English language education is one important component of the success of the Hong Kong education system.

\footnotetext{
${ }^{*}$ We thank an anonymous referee and seminar participants at the University of Hong Kong and at the WEA International Pacific Rim Conference for helpful comments.
} 